\title{
Külső katonai beavatkozás a szíriai polgárháborúba - Oroszország, Irán, Törökország és az Egyesült Államok szerepe ${ }^{1}$
}

\begin{abstract}
A 2011-ben az arab tavaszként emlegetett eseménysorozatba illeszkedő kormányellenes tüntetésekkel kezdődő szíriai válság az elmúlt nyolc év során a közel-keleti regionális hatalmi versengés egyik fö színtere lett, és napjaink egyik legösszetettebb polgárháborújává eszkalálódott. Menetének befolyásolása érdekében az államon belüli fegyveres konfliktusba több külső állami szereplő is beavatkozott proxyk támogatásával vagy akár katonai intervencióval is, ami az elemzők számára is nehezen átláthatóvá teszi a helyzetet. Irán már a polgárháború kibontakozásának eleje óta támogatja az Aszad elnökhöz hü kormányerőket, ám végül Oroszország 2015-ös katonai beavatkozása menthette csak meg a rezsimet a teljes összeomlástól. Teherán és Moszkva pragmatikus együttmüködésének köszönhetően a polgárháború menete egyértelmú irányt vett, miközben az Iszlám Állam terjeszkedése, majd Törökország kurdok elleni észak-szíriai hadmüveletei tették még összetettebbé a konfliktust. Az Amerikai Egyesült Államok (a továbbiakban: USA, Egyesült Államok) az Iszlám Állam felszámolására fókuszáló, az amerikai katonai szerepvállalást kifejezetten kerülő stratégiájával szinte lemondott Szíriáról. A tanulmány röviden összefoglalja a szíriai polgárháború eszkalálódásának történetét, ismerteti az orosz katonai intervenció és az orosz-iráni együttmüködés jelentőségét, majd felvázolja az észak-szíriai kurdok elleni török hadmúveletek szerepét, s végül kitér az Egyesült Államok szíriai stratégiájára is. A meghatározó külső állami szereplők szerepvállalásának ismertetésével a tanulmány rámutat a szíriai polgárháború külső hatalmi dimenziójának összetettségére, amely csak egy a sok közül.
\end{abstract}

Kulcsszavak: Közel-Kelet, sziriai polgárháború, intervenció, Oroszország, Törökország

\section{Selján Péter: Foreign military intervention in the Syrian civil war - The role of Russia, Iran, Turkey and the United States}

The Syrian crisis, which began in 2011 with anti-government protests (that formed part of what is referred to as the Arab Spring), has been at the center of regional power rivalry in the Middle East over the past eight years and it has escalated into one of the most complex civil wars of the 21st century. To shape the course of the domestic armed conflict, several external state actors got involved, supporting proxies or even direct military intervention. Iran has been supporting government forces loyal to President Assad since the beginning of the civil war, but in the end only Russia's military intervention could save the regime from collapsing in 2015. Due to the pragmatic cooperation between Tehran and Moscow, the course of the civil war took a clear direction, while the expansion of the Islamic State and Turkey's operations against the Kurds in Northern Syria made the conflict even more complex.

Jelen publikáció a BCE EFOP-3.6.3-VEKOP-16-2017-00007 azonosítószámú „Tehetségből fiatal kutató” - A kutatói életpályát támogató tevékenységek a felsőoktatásban címü projekt keretében jött létre. 
The United States, with its strategy of focusing narrowly on the eradication of the Islamic State and explicitly avoiding widespread US military engagement, practically gave up Syria. This paper briefly summarises the history of the escalation of the Syrian Civil War, sheds light on the importance of the Russian military intervention and the Russian-Iranian cooperation, then outlines the role of Turkish operations against the Kurds in Northern Syria, and finally touches on the United States' Syria strategy. By discussing the role of the major external state actors, this paper points out the complexity of the external dimensions of the Syrian civil war, which is only one of several perspectives.

Keywords: Middle East, Syrian civil war, Intervention, Russia, Turkey

\section{Bevezetés}

A szíriai polgárháború a 21. század eleddig egyik legösszetettebb és legvéresebb fegyveres konfliktusa. A második kongói háború (1998-2003) után a már kilencedik éve zajló szíriai harcok jártak a második legtöbb áldozattal. A 2011. március 15-e óta tartó szíriai válság az elmúlt évek során egy államon belüli konfliktusból nemzetközi fegyveres konfliktussá eszkalálódott, amelyben a Bassár el-Aszad vezette szíriai rezsimhez hü kormányerők és szövetségesei állnak szemben a szíriai demokratikus ellenzéki erőkkel és szövetségeseivel. Emellett a relatíve egyszerü kormányoldal az ellenzéki erők ellen szembenállás mellett azonban több belső és külső szereplő is részt vesz a konfliktusban a rezsimmel és a felkelőkkel is szemben állva, ami nehezen átláthatóvá teszi az egész szíriai helyzetet, olykor még a szakértők számára is. A Szíriai Fegyveres Erők (SAF) és a főként szunnita ellenzéki csoportok mellett többek között szalafista dzsihadista fegyveresek (mint például az an-Núszra Front), a kurdokból és arabokból álló Szíriai Demokratikus Erők (SDF) és a gyakorlatilag mindenki számára ellenségnek számító Iszlám Állam harcosai állnak szemben egymással. A válság összetettségét pedig tovább fokozza az a tény, hogy az immár kilencedik éve húzódó polgárháborúnak már több külső állami szereplője is van, amelyek közvetetten proxyk támogatásával vagy akár közvetlenül katonai intervencióval avatkoztak be a konfliktusba, például Irán, Oroszország, Törökország és az Egyesült Államok.

A szíriai konfliktus az elmúlt évek során már számos nemzetközi kutatás és tanulmány tárgya volt, és a következő években vagy akár évtizedekben is várhatóan több tudományos munka készül majd róla, az előzményeiről, az eszkalációjáról és a következményeiröl egyaránt. Többek között azért is került épp ez a konfliktus a kutatók és a nemzetközi közvélemény érdeklődésének középpontjába, mert olyan összetett, és olyan sok szereplője van, hogy már a szakértőknek is nehéz átlátni. Jelen tanulmány a szíriai polgárháború külső/nemzetközi dimenziójának összetettségére, pontosabban a külső állami szereplők beavatkozására szeretne rávilágítani. Ennek érdekében az első oldalakon röviden felvázolja a polgárháború előzményeit, az arab tavaszt és a Szíriát érintő eseményeit, majd ismerteti a legnagyobb befolyású külső állami szereplők szíriai szerepvállalását, kezdve az orosz katonai intervenciótól az orosz-iráni együttműködésen és a kurdok elleni észak-szíriai hadmüveleteken át az Egyesült Államok Szíria-stratégiájáig. Ezt követően a tanulmány egy rövid összegzéssel, illetve a levonható következtetésekkel zárul. 


\section{Szíria és az arab tavasz}

Szíriában az ország 1946-os függetlenné válását követően közel 20 éven keresztül egy szunnita többségű hatalmi elit került vezető pozícióba. Ezekben az évtizedekben továbbra is az autokratikus kormányzás és a potenciális instabilitás jellemezte az országot. Komolyabb változás ebben először csak az Arab Újjászületés Szocialista Pártjának (Baasz Párt) 1963. márciusi hatalomátvételét követően állt be. Ennek a puccsnak az egyik fó résztvevője volt az alavita származású Háfez el-Aszad (1930-2000), aki 1970-ben egy évre miniszterelnök lett, majd 1971 márciusától 2000 júniusáig az elnöki székből irányította az országot. Az általa felépített politikai rendszer meghatározó elemei az erős elnöki pozíció, a Baasz Párt dominanciája a pártrendszerben és a baaszizmusnak mint ideológiának a vezető szerepe voltak. A fegyveres erők és a titkosszolgálatok vezetőinek többsége alavita származású személy lett, bár Aszad szélesebb alapra kívánta építeni hatalmának politikai bázisát, ezért igyekezett nagyobb teret hagyni a keresztény, a drúz, az iszmáilita és a cserkesz kisebbségeknek. A szunnita arab közösségből pedig elsősorban a tekintélyes kereskedőcsaládokkal igyekezett jó kapcsolatokat ápolni Damaszkuszban és Aleppóban. Ez a hatalmi struktúra évtizedekig kiállta az idők próbáját. ${ }^{2}$

A 19. századi európai történelemből a „népek tavasza” kifejezés ihlette arab tavasz elnevezést a 2010 és 2011 fordulóján a Közel-Keleten és Észak-Afrikában megindult tüntetéssorozatokra és a politikai átalakulásra elsősorban a nemzetközi média, majd az arab közbeszéd is alkalmazta. A magában az elnevezésben rejlő optimizmus azonban gyakorlatilag pár hónap alatt odalett, miután több érintett országban elhúzódó válság vagy adott esetben polgárháború alakult ki. Ettől eltekintve az arab tavasz kifejezést az először Tunéziában, majd további arab országokban is szárnyra kapó, tüntetésekkel kezdődő társadalmi és politikai átalakulás gyűjtőfogalmaként használjuk, tudva azt, hogy valójában országonként más és más folyamatokat takar. ${ }^{3}$ Az érintett hat ország közül végül háromban is polgárháború tört ki (Líbia, Szíria, Jemen), és eddig mindössze csak Tunéziában ment végbe valamilyen szinten békés, demokratikus átalakulás, ahol 2019 októberében Kaisz Szaid, egy konzervatív jogászprofesszor több mint 70\%-os támogatottsággal nyert az elnökválasztáson. ${ }^{4}$

Az arab tavasz által indukált politikai folyamatok 2011 márciusában érték utol Szíriát. ${ }^{5}$ A szíriai válság közvetlen előzményeként megemlítendő, hogy az eleinte Londonban orvosnak készülő Bassár el-Aszad mindössze 34 éves volt, amikor apja halálát követően 2000ben átvette Szíria vezetését a korábban egy balesetben váratlanul elhunyt testvére helyett. A fiatal elnök már a kezdetektől nehézségekkel került szembe, miután a 2001. szeptember 11-ei terrortámadások után Szíria is a „gonosz tengelye” államainak a szövetségesei közé sorolódott, így Damaszkusz is komoly nemzetközi nyomás alá került. A terrorizmus elleni háború megindítása és Irak amerikai megszállása is közvetetten hátráltatta a szíriai

\footnotetext{
Csıki Tamás - GAzDik Gyula: Stratégiai törekvések a szíriai válság kapcsán I., Nemzet és Biztonság, 7. évf., 2013/1-2., 43. o.

3 N. Rózsa Erzsébet: Az arab tavasz - A Közel-Kelet átalakulása, Osiris Kiadó - Külügyi és Külgazdasági Intézet, Budapest, 2015, 79-80. o.

4 Michael SAFI: Tunisia election: 'Robocop' Kais Saied wins presidential runoff, [online], 2019. 10. 14. Forrás: theguardian.com [2019. 11.05.]

5 A szíriai arab tavaszról bővebben lásd: N. RózsA: i. m., 180-188.
} 
reformfolyamatokat, Rafik Haríri volt libanoni miniszterelnök 2005. februári meggyilkolása pedig tovább fokozta Szíria elszigetelődését, mivel annak hátterében Damaszkuszt gyanították. ${ }^{6}$ Ennek következményeként Aszad 2005 áprilisában végül kivonta a szíriai erőket Libanonból.

A szíriai gazdaság 2005-2011 között átlagosan majdnem 5\%-os reál GDP-növekedést produkált, de a 2008-2009-es gazdasági világválság Szíriában is éreztette negatív hatásait, így a növekedés ellenére sem sikerült a mélyreható gazdasági problémákat rendezni. Fokozatosan nőtt a 10\% körüli munkanélküliség, ami leginkább a fiatalabb korosztályt érintette, ahol a 30\%-ot is elérte. A növekvő élelmiszer- és üzemanyagárak komoly gondokat okoztak a lakosságnak, és folyamatosan nőtt a mélyszegénységben élők száma. Mindezek ellenére 2011 januárjában, még az arab tavasz folyamatába illő szíriai tüntetéssorozatok előtt Aszad elnök stabilnak értékelte Szíria helyzetét, noha minden bizonnyal Damaszkusz is tisztában lehetett a tiltakozási hullám terjedésében rejlö veszélyekkel. ${ }^{7} 2011$. március 15-én végül Szíriában is országszerte kezdődtek kiterjedt, tömeges megmozdulások, és egyre gyakoribbakká váltak az összetüzések a biztonsági erők és a tüntetők között. Az ezt követő hetekben és hónapokban rendszeressé váltak, és ezeket a hadsereg bevetésével sem sikerült megfékezni, a hirtelen elkezdett reformpolitika pedig már túl kevés volt, túl későn. ${ }^{8}$ Ráadásul, mire Szíriában kibontakoztak a tüntetések, addigra Tunéziában már megbukott Ben Ali, Egyiptomban Hoszni Mubarak, a líbiai katonai intervenció pedig már az elökészítési fázisban volt.

\section{Az orosz katonai intervenció}

Oroszország és Szíria évtizedes múltra visszatekintő jó kapcsolatai szinte egyedülállók a közel-keleti térségben. ${ }^{9}$ Utóbbi 1946-os függetlenné válása óta áll fenn Moszkva és Damaszkusz között diplomáciai kapcsolat, az Aszad család pedig hagyományosan jó viszonyt ápolt az oroszországi vezetéssel. A hidegháború alatt a Szovjetunió lett Szíria egyik legfontosabb szövetségese, illetve fö fegyverszállítója. Ennek eredményeképpen 1972-ben biztonsági együttmüködési megállapodás, 1980-ban barátsági szerződés, 1983-ban pedig nukleáris együttműködési megállapodás is köttetett a felek között. Ezt a stratégiai együttmüködést fémjelzi a mai napig is a tartúszi orosz haditengerészeti bázis, amelyet Oroszország 1971 óta bérel Szíriától, lehetővé téve ezzel az orosz haditengerészet számára a földközi-tengeri jelenlétet. Az orosz-szíriai kapcsolatok első ízben 1985-ben szenvedtek némi visszaesést, miután Gorbacsov hatalomra kerülésével csökkentették Szíria katonai és gazdasági támogatásának mértékét. Tartúsz haditengerészeti kikötője azonban még a Szovjetunió széthullását követően is Oroszországé maradt, 2005-ben pedig Szíria tartozásai nagy részét

\footnotetext{
Susan SACHS: Rafik Hariri, Ex-Premier of Lebanon, Dies at 60, [online], 2005. 02. 15. Forrás: nytimes.com [2019. 10. 21.] Interview With Syrian President Bashar al-Assad, [online], 2011. 01. 31. Forrás: wsj.com [2019. 10. 29.]

GAzDik Gyula: Szíria az „arab tavasz” sodrában, Nemzet és Biztonság, 5. évf., 2012/4, 117-118. o.

Francesco Belcastro: Syrian Foreign Policy: The Alliances of a Regional Power, Routledge/St. Andrews Syrian Studies Series, London, 2019, 114-126. o.
} 
elengedve Moszkva cserébe engedélyt is kapott annak bővítésére. ${ }^{10}$ Legutóbb 2017-ben jött létre új bérleti szerződés Putyin és Aszad között a tartúszi kikötőről, újabb 49 évre. ${ }^{11}$

Oroszország Közel-Kelet-politikáját illetően megjegyzendő, hogy a hidegháborút követő első évtizedben, illetve a 2000-es évek elejéig a térség Moszkva számára teljesen a háttérbe szorult, így gyakorlatilag nem is szólt bele a régió eseményeinek alakulásába. A távolmaradást követő időszakban azonban már igyekezett növelni közel-keleti szerepét, ezért bekapcsolódott a régiót érintő fontosabb politikai ügyekbe, például az iráni atomvitáról szóló tárgyalásokba vagy az arab-izraeli békefolyamatba. A közel-keleti irányú külpolitikai aktivizálódásban az is szerepet játszott, hogy Oroszország többek között így kívánta ellensúlyozni az Egyesült Államok meghatározó befolyását a régióban, de fontos megemlítenünk, hogy a közel-keleti szerepvállalás Moszkva számára az iszlám radikalizmus oroszországi terjedésének megfékezéséhez is lehetőséget szolgáltatott. Mindezek mellett a legtöbb szakértő általában egyetért abban, hogy Oroszország számára a közel-keleti térség nem élvez prioritást. ${ }^{12}$

Ahogy azt már korábban említettük, Szíria számára Rafik Haríri, a Libanonban állomásozó szíriai katonai erők kivonását követelő libanoni ex-kormányfö 2005. februári meggyilkolását követően értékelődött fel igazán Oroszország diplomáciai és katonai támogatása, mivel a merénylet hátterében a nemzetközi közösség Szíriát gyanította. Ezt követően az orosz diplomáciai támogatás - például az Egyesült Nemzetek Szervezetének Biztonsági Tanácsában a Szíriával szembeni határozatok elutasítása - mellett fokozatosan erősödött a két ország katonai együttmüködése is, amelynek eredményeképpen a Szíriának juttatott fegyverszállítások értéke 2006 és 2011 között elérte az 5,5 milliárd dollárt, ami a szíriai fegyverimport $78 \%$-át jelentette akkor. ${ }^{13}$

$\mathrm{Az}$ arab tavasz eseménysorozatából a szíriai válság lett a legfontosabb Oroszország számára, már csupán az előbb említett fegyverexport és a tartúszi haditengerészeti bázis miatt is, de mindenképp meg kell még említenünk az iszlám radikalizmus, pontosabban az észak-kaukázusi és a közép-ázsiai iszlamista befolyás terjedését is, mint a szíriai konfliktus alakulásának jelentőségét Moszkva számára fokozó tényezőt. ${ }^{14} \mathrm{Az}$ Aszad-rezsim bukás szélére kerülése azért is érintette kellemetlenül és állította komoly dilemma elé az orosz vezetést, mert Moszkva számára a közel-keleti status quo fenntartásához elengedhetetlen Szíria stabilitása. ${ }^{15} \mathrm{Az}$ Aszad-rezsim esetleges bukása Oroszország számára gyakorlatilag a régióból történő kiszorulást jelentené, amellyel egyúttal nagyhatalmi státusza is redukálódna. ${ }^{16}$ Miután Moszkva részéről világossá vált, hogy Damaszkusz nem tud úrrá lenni

10 Póti László - N. Rózsa Erzsébet: Oroszország Szíriában: nem második ukrán front, Külügyi és Külgazdasági Intézet, KKI-elemzések, E-2015/38, 3. o.

11 Yuras KarmanaU: Naval base in Syria anchors Russia to Mediterranean, [online], 2019. 09. 26. Forrás: navytimes.com [2019. 10. 21.]

12 TÁLAs Péter - VARgA Gergely: Stratégiai törekvések a szíriai válság kapcsán II., Nemzet és Biztonság, 6. évf., 2013/1-2, 73. o.

13 David Kenner: What Russia Gave Syria, A guide to Bashar al-Assad's arsenal, [online], 2012. 06. 21. Forrás: foreignpolicy.com [2019. 10. 21.]

14 Ruslan Pukhov: Why Russia Is Backing Syria, [online], 2012. 07. 06. Forrás: nytimes.com [2019. 10. 22.]

15 Sz. Bínó Zoltán: Oroszország külpolitikája (2012-2016): a nagyhatalmiság kísértése, Nemzet és Biztonság, 8. évf., 2016/6, 34-40. o.

16 Selján Péter: Oroszország és a szíriai polgárháború, Nemzet és Biztonság, 8. évf., 2016/5, 19-20. o. 
a kialakult válsághelyzeten, Putyin orosz elnök végül inkább a katonai beavatkozás mellett döntött, amivel sikerült is megmentenie Aszadot a bukástól, miközben az ENSZ Biztonsági Tanácsában Oroszország Kínával karöltve valamennyi határozattervezetet elutasított, ami elítélte volna Szíriát vagy esetleg szankciókkal fenyegette volna az Aszad-rezsimet. ${ }^{17}$ Bár az orosz katonai beavatkozás hivatalosan csak 2015 szeptemberében vette kezdetét, megjegyzendő, hogy nem-harcoló orosz erők már 2013 óta jelen voltak Szíriában, elsősorban hivatalos tanácsadói minőségben, vagy éppen a Wagner orosz katonai magánvállalat „alkalmazottaiként" ${ }^{18}$

Putyin orosz elnök 2015. szeptember végén kapott felhatalmazást a törvényhozástól az orosz fegyveres erők Szíriában történő bevetésére „terrorszervezetek megfékezése érdekében”, miután Damaszkuszból hivatalos, Aszad katonai segítségkérését tartalmazó levél érkezett Moszkvába. Az orosz légierő által az intervenció keretében végrehajtott bombatámadásoknak azonban az Egyesült Államok és szövetségesei szerint az Iszlám Állam harcosai mellett többször az ellenzéki fegyveresek lehettek inkább a célpontjai. ${ }^{19}$ A katonai intervencióval Oroszország legfőbb célja egyértelmüen az volt, hogy megmentse az Aszadrezsimet a küszöbön álló összeomlástól, illetve hogy meghatározó szereplőjévé váljon az Egyesült Államokkal szemben a szíriai polgárháború rendezésének. Noha 2016 márciusában Putyin elnök váratlanul bejelentette az orosz erők részleges visszavonását Szíriából, mondván, hogy a katonai beavatkozás elérte a kitüzött célokat, az orosz katonai jelenlét gyakorlatilag állandósult Szíriában. ${ }^{20} \mathrm{~A}$ részleges csapatkivonás minél korábbi bejelentése elsősorban anyagi okokból volt logikus és szükséges lépés, tekintettel arra, hogy miközben a katonai kiadások megemelkedtek, a szíriai katonai intervenciót megelőző években jelentős mértékben gyengült az orosz gazdaság, különösen az olajárak 2014. júniusi csökkenése, az orosz rubel közel 50\%-os leértékelődése (2014 második felében), illetve az év végén a Krím annektálása miatt Oroszországgal szemben bevezetett nyugati szankciók nyomán. ${ }^{21}$

Egyes szakértők szerint Putyin a szíriai szerepvállalást igyekszik folyamatosan úgy alakítani, hogy a kitüzött cél - az orosz befolyás megerősítése - eléréséhez csupán a feltétlenül szükséges gazdasági és katonai erőforrásokat használják fel, kerülve az észszerütlen mértékü anyagi és katonai áldozatokat. Ennek érdekében pedig Moszkva rendre a diplomácia és a katonai intervenció kombinációját alkalmazza. Stratégiája sikeresnek is tekinthető, hiszen Oroszország a szíriai válság rendezésének megkerülhetetlen szereplöjévé vált. ${ }^{22}$ John Hannah szerint az Egyesült Államok kiforratlan stratégiája miatt csökkent az amerikai

17 Legutóbb 2019. szeptember 19-én utasított el Oroszország egy a szíriai válsággal kapcsolatos BT határozatot, immár a tizenharmadik alkalommal. Michelle Nichols: Russia casts 13 th veto of U.N. Security Council action during Syrian war, [online], 2019. 09. 19. Forrás: reuters.com [2019. 10. 22.]; Alexey VAsiliev: Russia’s Middle East Policy: From Lenin to Putin. Durham Modern Middle East and Islamic World Series (Book 46), Routledge, Abingdon, 2018, 472-475. o.

18 A Wagner Csoport egy orosz kötődésű katonai magánvállalat (Private Military Company, azaz PMC), amely szoros kapcsolatokat ápol az orosz vezérkar Felderítő Főigazgatóságával (GRU), és leginkább az orosz fegyveres erők, illetve a GRU fő feladatait alvállalkozóként végrehajtó proxyhadseregként működik. Erről bővebben lásd: RÁcz András JójÁRT Krisztián: A Deir ez-Zór incidens: amerikai légicsapás orosz zsoldosok ellen Szíriában, Nemzet és Biztonság, 10. évf., 2018/2, 57-65. o.

19 Russia joins war in Syria: Five key points, [online], 2015. 10. 01. Forrás: bbc.com [2019. 10. 22.]

20 Neil MacFarquhar - Anne Barnard: Putin Orders Start of Syria Withdrawal, Saying Goals Are Achieved, [online], 2016. 03. 14. Forrás: nytimes.com [2019. 10. 22.]

${ }^{21}$ Jasmine C. LeE: Why the Russian Economy Is Tumbling, [online], 2016. 04. 12. Forrás: nytimes.com [2019. 10. 23.]

22 Dmitry Adamsky: Putin's Game in Syria, [online], 2016. 04. 03. Forrás: foreignaffairs.com [2019. 10. 23.] 
befolyás a Közel-Keleten, aminek egyenes következménye volt Oroszország fokozódó aktivitása a térségben. Megjegyzendő, hogy míg az Obama-adminisztráció a szíriai polgárháború elején rendszeresen elvetette a közvetlen katonai beavatkozás lehetőségét, addig az orosz katonai intervenció az Aszad-rezsim oldalán gyakorlatilag eldöntötte a polgárháború menetét, megmentve Aszad elnök rendszerét a teljes bukástól. Az orosz katonai jelenlét ráadásul jelentős mértékben korlátozta az amerikai erők mozgásterét Szíriában. Putyin következetes és pragmatikus politikájával lényegében sikeresen ki tudta használni a gyakran zavarosnak tűnő és nehezen értelmezhető, világos stratégiai irányt kevésbé mutató nyugati Szíria-politika gyengeségét és hiányosságait. ${ }^{23}$

Az orosz katonai intervenciónak már az első éve alatt jelentős mértékben megváltoztak az erőviszonyok. A 2015 nyarán a bukás szélére került Aszad-rezsimnek sikerült pozícióit megszilárdítani. Bár a fennhatóságát továbbra sem tudja az ország egész területére kiterjeszteni, Aszad elnök joggal érezhette/érezheti úgy, hogy szinte nullára redukálódott annak az esélye, hogy az ellenzéki erők megbuktassák a damaszkuszi kormányt. Ezzel párhuzamosan azonban a konfliktus rendezési kísérleteinek sorozatos kudarcai miatt tovább nőtt az ország szétesésének az esélye, ami rávilágított a több mint száz éve aláírt Sykes-Picotegyezményen alapuló jelenlegi regionális status quo hosszú távú fenntarthatóságával kapcsolatos kérdésekre. ${ }^{24}$

Dmitry Adamsky szerint Oroszországnak a szíriai katonai intervencióval több nemzetközi, regionális és belföldi célja is volt. Az egyik fö cél magától értetődően az volt, hogy megmentse a szövetséges Aszad-rezsimet a bukástól és biztosítsa Oroszország katonai és politikai érdekeltségeit Szíriában, megelőzve a rezsimbuktató „líbiai forgatókönyv” megismétlődését. Emellett további célként fogalmazódott meg az is, hogy megelőző csapást mérjen a posztszovjet térségből származó dzsihadistákra, akik Oroszország számára komoly biztonsági fenyegetést jelenthetnek. A szíriai beavatkozásnak egy figyelemelterelő szerepe is volt, hiszen így az ukrajnai válság helyett a közel-keleti konfliktusra irányult a nemzetközi közösség figyelme. Nem utolsósorban pedig az is a célok között szerepelhetett, hogy Oroszország növelje regionális befolyását, hogy megkerülhetetlen nemzetközi szereplőként helyezkedhessen szembe az Egyesült Államokkal. Ezen célok elérése érdekében a szíriai szerepvállalása során Oroszország három stratégiai alapelvet követ, amelyek közül az egyik legfontosabb a „kontrollált feszültségek” fenntartása, ami lényegében azt jelenti, hogy Moszkva igyekszik az egyes felek közötti konfliktusokat egy még kezelhetö, közepes szinten tartani, biztosítva a lehetőséget, hogy Oroszország egyszerre lehessen része a megoldásnak és a problémának egyaránt. A második alapelv az észszerủ mértékü szerepvállalás, ami azért fontos, hogy Oroszország ne vállalja túl magát katonailag, hanem egy arany középutat választva, csak a feltétlenül szükséges erőkkel avatkozzon be. A harmadik pedig a „stratégiai finomhangolás”, ami azt jelenti, hogy Moszkva rendszeresen újraértékeli a stratégiáját az események alakulásának tükrében, és amennyiben szükséges, módosításokat eszközöl a siker érdekében. Ez a fajta stratégiai rugalmasság a merev, kötött

\footnotetext{
23 John Hannah: Russia’s Middle East Offensive, [online], 2016. 09. 13. Forrás: foreignpolicy.com [2019. 10. 23.]; Anna Borshchevskaya: Russia’s Goals Go Beyond Damascus, Middle East Quarterly, 25. évf., 2018/1, 1-13. o.

24 Gazdik Gyula: Szíriai válság: „geopolitikai Csernobil”? (I.), Nemzet és Biztonság, 8. évf., 2016/5, 107-108. o.
} 
elképzelésekhez ragaszkodással szemben jól illeszkedik a csak az észszerü mértékű erőforrások alkalmazásának szükségességét szem előtt tartó orosz stratégiai hozzáálláshoz. ${ }^{25}$

\section{Irán és Oroszország együttmúködése Szíriában}

A szíriai válság egyik fontos külső szereplője a regionális hatalomként a konfliktusban gyakorlatilag közvetlenül is érintett síita Irán. Teherán az arab tavasz eseménysorozatának elején az arab országok lakosságának tiltakozási hullámait igyekezett az 1979-es iráni iszlám forradalomhoz hasonlítani. A szíriai konfliktus nemzetközivé szélesedése azonban nehéz helyzetbe hozta a perzsa államot is. A polgárháborús szituációban Szíria a regionális hatalmi pozícióért zajló versenyfutás egyik fö (had)színterévé vált. Teherán számára azért is fontos, hogy az iszlám síita ágához köthető alavita kisebbség megőrizhesse vezető szerepét Damaszkuszban, mert többek között így tudhatja biztosítottnak a Földközi-tengerig húzódó befolyási övezetét. A szíriai tüntetések eldurvulásáért Irán az Egyesült Államokat és Izraelt okolta, az Aszad-rezsim megerősítését pedig az egyik legfőbb védőbástyának tekintette Washington és a zsidó állam „trükkjeivel” szemben, ezért is igyekezett és igyekszik Aszadot hatalmon tartani. ${ }^{26} \mathrm{~A}$ perzsa állam regionális befolyását növelte az elmúlt évtizedekben, hogy az Egyesült Államok által indított terrorizmus elleni háború keretében először megdöntötték Irán keleti szomszédságában az afganisztáni tálib rendszert 2001-ben, majd pedig 2003-ban Irán nyugati szomszédjában, Irakban is sor került egy rezsimbuktató amerikai katonai intervencióra. A szunnita Szaddám Huszein bukásával nagyobb mozgásteret nyertek a síita iraki csoportok, ami Irán hatalmi befolyását is növelte az országban. A Teherán és Damaszkusz közötti kapcsolatok is sokat javultak ezekben az években, bár már az iraki-iráni háború (1980-1988) alatt is a perzsa állam egyik fontos szövetségese volt Szíria. ${ }^{27}$

Damaszkusz és Teherán partnersége már négy évtizedes múltra tekint vissza. ${ }^{28}$ Annak ellenére is, hogy a szekuláris pánarabista Szíria és a teokratikus pániszlamista Irán közötti különbségeket korábban túl mélynek tekintették ahhoz, hogy hosszú távú együttmüködés alakulhasson ki közöttük, még ha arra éppenséggel közös érdekek miatt szükség is lenne. A mindkét országot hasonlóan érintő geopolitikai tényezők és a fenyegetettségi percepcióik révén azonban a partnerségük nemcsak hogy fennmaradt, de el is mélyült. ${ }^{29}$ Damaszkusz és Teherán is ellenzi az Egyesült Államok által szorgalmazott regionális rendet, ezért igyekeznek csökkenteni az amerikai befolyást a térségben. Ez a közös érdek pedig elég nekik ahhoz, hogy ideológiai nézeteltéréseiken felülemelkedve együttmüködjenek egy önállóbb, nyugati befolyástól mentes Közel-Kelet érdekében. 2011 óta Irán többször is demonstrálta az Aszad-rezsim melletti elkötelezettségét, és az egyik meghatározó külső szereplőjévé vált

25 Dmitry Adamsky: Moscow's Syria Campaign: Russian Lessons for the Art of Strategy, [online], Russie.Nei.Visions, No. 109, 2018, 6-8. o. Forrás: ifri.org [2019. 10. 08.]

26 Geneive Abdo: How Iran Keeps Assad in Power in Syria, [online], 2011. 08. 25. Forrás: foreignaffairs.com [2019. 11. 01.]; W. Andrew Terrill: Iran's Strategy for Saving Asad, Middle East Journal, 69. évf., 2015/2, 222-236. o.

27 CsIKI-GAZdiK: i. m., 53.

28 Belcastro: $i$. m., 91-102.

29 Jubin M. Goodarzi: Syria and Iran: Diplomatic Alliance and Power Politics in the Middle East, Tauris, London, 2006. 
a szíriai polgárháborúnak, amit az elemzők egy része valamilyen expanzionista törekvésként szokott értékelni, ${ }^{30}$ vagy épp szektariánus nézőpontból értelmezi az eseményeket, ${ }^{31}$ esetleg Teherán Izrael-ellenes ideológiáját helyezi a középpontba. ${ }^{32}$ Mindezek mellett azonban mindenképpen számításba kell vennünk Irán jogos biztonsági aggodalmait és fenyegetettségi percepcióit. Egyes elemzők szerint Szíria és Irán kapcsolata az ideológiai, geopolitikai vagy szektariánus tényezők helyett inkább az elrettentés stratégiájára épül már az iráni iszlám forradalom óta. ${ }^{33}$

A szíriai tüntetéssorozatot az iráni elit eleinte kétféle megközelítésben értelmezte. $\mathrm{Az}$ arab tavaszos megközelítés szerint Iránnak a szíriai népet kell támogatnia a diktatórikus rendszerrel szembeni felkelésben. Egy másik megközelítés azonban a szíriai válságnak a regionális hatalmi egyensúlyra gyakorolt hatására fókuszált, az ellenzéki tüntetéseket egy külső szereplő által indukált és támogatott rezsimbuktató kísérletként értékelve, amelynek célja a hatalmi egyensúly kibillentése Iránnal szemben. Ennek fényében Teherán nem nézhette tétlenül, ahogy egyre több nemzetközi és regionális szereplő szorgalmazta Aszad távozását a hatalomból, hiszen a szíriai rezsimváltás Irán számára is fenyegetést jelentett volna. Ez leginkább azt követően vált nyilvánvalóvá Irán számára, miután Barack Obama amerikai elnök 2011 augusztusában bejelentette, hogy eljött az idő Aszad elnök lemondására. ${ }^{34} \mathrm{Az}$ amerikai elnök felszólítását Teheránban úgy értékelték, hogy ezzel a szíriai válságban egy új fejezet kezdődik, amelyben az Egyesült Âllamok és szövetségesei egy rezsimbuktató intervenciót hajthatnak végre Szíriában, amivel alááshatnák Iránnak az „előretolt elrettentés” stratégiáját. Látva az események alakulását és figyelembe véve minden geopolitikai tényezőt, Irán számára a szíriai polgárháború már nem a szíriai népről, az emberi jogokról vagy politikai és gazdasági reformokról, hanem pusztán geopolitikai érdekekről szólt. ${ }^{35}$ Teherán éppen ezért gyakorlatilag a szíriai konfliktus legeleje óta nyújt támogatást a kormányerőknek, hogy megakadályozza az Aszad-rezsim bukását, ami súlyos stratégiai veszteség volna számára. ${ }^{36}$

Oroszország beavatkozását a szíriai polgárháborúba éppen Irán szorgalmazta a leginkább, mégpedig három okból is. Az egyik fö ok az volt, hogy a szíriai kormányerők 2015 őszére már egyértelműen vesztésre álltak az ellenzéki felkelőkkel szemben, miközben az Iszlám Állam terjeszkedése is egyre komolyabb fenyegetést jelentett az Aszad-

30 Marc Champion - Jonathan Ferziger - David Wainer: Israel, Saudis Find Common Cause in Warning of Iran Expansionism, [online], 2018. 02. 18. Forrás: bloomberg.com [2019. 11. 22.]

31 Basheer NAFI: Iran's sectarian wars must be confronted, but not with more of the same, [online], 2017. 03. 16. Forrás: middleeasteye.net [2019. 11. 22.]

32 Karim SAdjadpour: Iran's Real Enemy in Syria, [online], 2018. 04. 16. Forrás: theatlantic.com [2019. 11. 22.]

33 Hassan Ahmadian - Payam Mohseni: Iran's Syria strategy: the evolution of deterrence, International Affairs, 95. évf., 2019/2, 341-343. o.

34 Jason Ukman - Liz SLY: Obama: Syrian President Assad must step down, [online], 2011. 08. 18. Forrás: washingtonpost. com [2019. 11.22.]

35 Ahmadian-Mohseni: i. m., 353-354.

36 Irán szíriai stratégiája 2011-től négy szakaszra osztható Ahmadian és Mohseni szerint: (1) az első fázisban a „Basij” stratégia értelmében helyi milíciákat szerveztek Szíriában; (2) a második fázisban a „regionalizációs” stratégia keretében külföldi milíciákat vontak be a harcokba, így a libanoni Hezbollah 2013-ban kapcsolódott be a szíriai polgárháborúba; (3) a harmadik szakaszban az „internacionalizációs” stratégia jegyében Irán egyensúlyozó erőként bevonta Oroszországot a konfliktusba az Egyesült Államokkal szemben; (4) míg a negyedik fázisban az Iszlám Állam utáni időszak elrettentési stratégiájának végrehajtása zajlik az Egyesült Államokkal, Törökországgal és Izraellel szembeni egyensúlyozás érdekében. Ahmadian-Mohseni: i. m., 355-363. 
rezsim számára. Emellett Irán úgy látta, hogy ki kell egyensúlyoznia az Egyesült Államok és Törökország szíriai pozíciószerzését, amire az Iszlám Állammal szembeni nemzetközi fellépésük eredményeképpen kerülhetett sor. Oroszország támogatásával a szíriai kormányerők és szövetségeseik visszaszoríthatták az ellenzéki erőket, és az orosz légierő az amerikai légierővel szemben is jó ellensúlyt képezhetett a szíriai légtérben. Harmadrészt megemlítendő egy belpolitikai tényező, mivel az iráni nukleáris megállapodást (JCPOA) 2015-ben írták alá, konzervatív iráni vezetők pedig úgy látták, hogy a túlzott nyugati közeledést megelőzve eljött az ideje a szorosabb együttműködésnek Moszkvával. Irán számára ebben a tekintetben az orosz katonai beavatkozás mindhárom problémára megoldást jelentett, miközben Oroszország is fokozott óvatossággal és gyanakvóan figyelte az Egyesült Államok Szíriával kapcsolatos rezsimbuktató terveit, és ezért is igyekezett megakadályozni az ENSZ Biztonsági Tanácsában a Damaszkuszt elítélő határozatok elfogadását. Oroszország 2015. szeptemberi katonai intervenciójával a szíriai konfliktus alakulása Aszad pozíciójának megerősítésével végül teljesen új irányt vett. ${ }^{37}$ Moszkva és Teherán az Aszad-rezsim támogatóiként a legbefolyásosabb külső állami szereplőivé váltak a szíriai polgárháborúnak, és várhatóan az elsők között kívánnak majd haszonhoz jutni a szíriai gazdaság talpra állásából, amennyiben a konfliktus idővel valóban nyugvópontra jut, és megkezdődik az ország újraépítése. ${ }^{38}$

\section{A kurdok elleni török hadmüveletek}

A válság elején Szíria még az Ahmet Davutoğlu akkori török külügyminiszter által vezetett „zero problem policy”, azaz a szomszédos országokkal problémamentes kapcsolatok szükségességének elvére épülő külpolitikai koncepció egyik meghatározó eleme volt, ahol végül gyakorlatilag ütközésbe került egymással a rövid távú pragmatizmus és a hosszú távú stratégiai koncepció. Davutoğlu külügyminiszterségének (2009-2014) elején liberalizálták a török-szír kereskedelempolitikát, Szíriában növelték a török tőkebefektetéseket, és közös kőolajkitermelési és exporttevékenységbe kezdtek. Ez a kereskedelmi és a gazdasági mutatókban is megmutatkozott, a két ország közötti kereskedelem 2000 és 2008 között két és félszeresére nőtt. Mindemellett zajlottak a tárgyalások egy szabadkereskedelmi övezet létrehozásáról, 2009-ben pedig a szír állampolgárok vízummentességet kaptak Törökországban. A jó kapcsolatok azonban a szíriai események kapcsán 2011-től fokozatosan romlottak. Ankara eleinte nyomásgyakorlással igyekezett rábírni az Aszad-rezsimet a szükséges politikai reformok végrehajtására a válság elmélyülésének megakadályozása érdekében. Miután a reformok elmaradtak, a tüntetések pedig végül a kormányerők és a rendszerellenes felkelök közötti fegyveres összecsapásokká eszkalálódtak, Törökország egyre határozottabban szólította fel az Aszad-rezsimet a fegyveres fellépés leállítására, és békés politikai megoldást sürgetett. ${ }^{39}$ Ankara hivatalosan 2011 novemberében állt ki

\footnotetext{
37 Ahmadian-Mohseni: $i$. m., 359.

38 Sinan Hataheт: Russia and Iran: Economic Influence in Syria, [online], Chatham House, Middle East and North Africa Programme Research Paper, March 2019. Forrás: chathamhouse.org [2019. 10. 08.]; Faysal ITANI: Geo-economics: Russia and Iran in Syria, Syria Studies, 11. évf., 2019/1, 23-31. o.

39 Csiki-Gazdik: i. m., 46-47.
} 
az ellenzéki erők mellett, egy hónappal később pedig a Szíriai Nemzeti Tanács (SNC) Isztambulban nyitotta meg első irodáját. ${ }^{40}$

Egyes szakértők már a polgárháború kialakulásának az elején figyelmeztettek, hogy Törökország nem csupán a politikai rendezés egyik szereplője, hanem akár a további eszkaláció forrása is lehet. Csiki Varga Tamás és Gazdik Gyula a szíriai válsággal foglalkozó egyik tanulmányukban emlékeztetnek rá, hogy az arab tavasz eseménysorozatából a szíriai polgárháború különös fontossággal bír Törökország számára, ezért a szomszédos országban zajló eseményeket Ankara már a török nemzeti biztonsági érdekeket közvetlenül érintő kockázatokat figyelembe véve értékeli, és akár fegyveres erővel is kész fellépni, ha szükséges. A török vezetés számára ugyanis a szíriai válság komoly kockázatokat rejtett és rejt magában továbbra is, mint például a szír vezetéssel megbomló kapcsolatok, a konfliktus kedvezőtlen gazdasági hatásai, a menekültválság kezelésének problémája, a kurdok helyzetének megerősödése Törökországban és Szíriában egyaránt, a fegyveres konfliktus további eszkalációja Észak-Irak felé vagy a török-iráni kapcsolatok romlása. ${ }^{41}$

A török-szír kapcsolatok először 2012-ben kerültek mélypontra, azt követően, hogy a szíriai kormányerők lelöttek egy F-4 Fantom típusú török harci repülőgépet, bár végül ez az eset nem járt súlyos következményekkel. ${ }^{42}$ Pár hónappal később ismét feszültté vált a helyzet, miután szíriai tüzérségi tüz érte a határ mentén található Akçakale török város külterületét öt civil halálát okozva, és ezúttal a határ mentén tüzérségi válaszcsapásokhoz vezetett. ${ }^{43}$ Ekkorra már olyan szintre fokozódott a feszültség a térségben, hogy a török parlament felhatalmazást adott szíriai katonai műveletek megindítására is, amennyiben intervencióra lenne szükség Törökország védelme érdekében. Ez a döntés azért is volt fontos fordulat a polgárháború alakulásában, mert ez volt az első alkalom, hogy egy ország kormánya az Aszad-rezsimmel szembeni katonai fellépést helyezett kilátásba, és a fegyveres eröknek erre felhatalmazást is adott a törvényhozás. ${ }^{44}$ Ezzel együtt értelemszerủen a válság további eszkalációja miatti aggodalom is megnőtt.

Megjegyzendő, hogy Törökország számára a szíriai válság alakulása nemcsak a polgárháborús helyzet miatt fontos, hanem a Kurd Munkáspárt (PKK) törökországi és szíriai befolyásának esetleges növekedésében rejlő veszélyek, a kurd fenyegetés megerősödése miatt is. Emellett fontos kérdés Ankara számára a szíriai kurd autonómia kialakulásának lehetősége is, ami a török álláspont szerint komoly biztonsági fenyegetést jelenthet Törökország számára. Ebből adódóan a szíriai kurdok és a velük szembeni török politika potenciálisan nem csupán a szíriai konfliktus rendezésében, de annak eszkalációjában is fontos szerepet

40 Sebnem Arsu: Turkish Premier Urges Assad to Quit in Syria, [online], 2011. 11. 22. Forrás: nytimes.com [2019. 10. 31.]; Emre Peker: Syria’s Main Opposition Group Opens First Office in Istanbul, [online], 2011. 12. 14. Forrás: bloomberg. com [2019. 10.31.]

41 Csiki-Gazdik: i. m., 45-46.

42 Constanze Letsch: Assad regrets Syrian forces shooting down Turkish fighter plane, [online], 2012. 07. 03. Forrás: theguardian.com [2019. 10.31.]

43 Liz SLY: Turkey strikes back at Syria after shell kills at least 5 Turkish civilians, [online], 2012. 10. 03. Forrás: washingtonpost.com [2019. 10.31.]

44 Bradley Secker - Janelle Dumalaon: Turkey authorizes military operations in Syria, [online], 2012. 10. 05. Forrás: eu.usatoday.com [2019. 10.31.] 
tölthetnek, illetve töltöttek be eddig is. A szíriai kurdoknak ennek köszönhetően sikerült az elmúlt években saját mozgásterük szélesítésére kihasználni a helyzetet. ${ }^{45}$

Mint ismeretes, az összességében körülbelül 30-40 milliós, Törökország, Irán, Irak és Szíria területein élő kurd közösség a Közel-Kelet legnagyobb kisebbsége. ${ }^{46}$ A 20. században számos alkalommal próbálkoztak a függetlenedéssel, ám a külső hatalmak és leginkább a közvetlenül érintett négy ország kormányzatainak ellenkezése miatt ez irányú törekvéseik nem járhattak sikerrel. Kurd autonómia így eddig csak Irakban jött létre a Kurdisztáni Regionális Kormányzat (KRG) létrehozásával, amely mellett még az észak-szíriai Rodzsava nevü kurd terület említhető példaként, ahol a kurd fegyveresek az elmúlt években de facto autonómiát vívtak ki maguknak, noha státuszuk tisztázatlan maradt. A szíriai kurdok függetlenedési törekvései a polgárháború kialakulásának az elején erősödtek meg, miután az Aszad-rezsim katonai egységei 2012-ben kivonultak az észak-szíriai kurd területekről, mivel a kormányellenes felkelőkkel szembeni harcokhoz más területekre kellett átcsoportosítani az erőket. ${ }^{47}$ Ezt követően a szíriai kurdok sikeresen megszervezték saját védelmi egységeiket, hogy fel tudják venni a harcot a különböző ellenséges fegyveres csoportokkal és a szélsőséges iszlamistákkal szemben. 2012-ben a kurdok lakta szíriai területeken a Demokratikus Egyesülés Pártja (PYD) szerezte meg a hatalmat, majd létrehozta a Népi Védelmi Erőket (YPG), amely később a 2015 októberében létrehozott Szíriai Demokratikus Erők legerősebb tagjaként meghatározó szerepet töltött be az Iszlám Állam legyőzésében, 2014 decemberétől pedig az USA fő szövetségese volt Szíriában. ${ }^{48}$

A szíriai kurdok katonai sikereit, illetve a YPG számára nyúitott külföldi (elsősorban amerikai) támogatás mértékét azonban Törökország aggódva figyelte. Miután a YPG sikerrel védte meg az Iszlám Állam fegyveresei által ostrom alá vett Kobanét, a kurdok ellentámadást indítottak, és végül 2017-ben elfoglalták Rakkát, 2018-ra pedig az Eufrátesztől keletre eső területek nagy részét. Mindeközben 2016-ban kísérletet tettek az utóbbi területek és az afríni kanton összekötésére, ám a területek egyesülését végül Törökország megakadályozta az általa indított Eufrátesz Pajzsa hadművelet megindításával 2016. augusztus végén. A sikereiktől ittasan a kurdok 2016 márciusában az autonómiájuk megerősítésének érdekében Rodzsava néven (Észak-szíriai Föderáció) létrehoztak egy föderális berendezkedésű entitást, amit azonban az Egyesült Államok sem fogadott el. ${ }^{49}$ Törökország másodízben 2018. január 20-án indított katonai offenzívát Észak-Szíriában (Olajág hadművelet), méghozzá az afríni kurd régió ellen, gyakorlatilag a korábbi, Eufrátesz Pajzsa hadművelet folytatásaként. A 6400

45 Csiki-Gazdik: i. m., 50.

46 David McDowall: A Modern History of the Kurds, I. B. Tauris, London - New York, 2017, 466-467. o. A kurdok számáról nem állnak rendelkezésre pontos adatok. A különböző becslések szerint a legnagyobb számban Törökországban (13-15 millió fö) élnek. Iránban közösségük körülbelül 6-8 millió, Irakban 4-5 millió, Szíriában pedig 1,5-2 millió fős. Mindemellett megemlítendő még, hogy Európában több százezres kurd diaszpóra alakult ki az elmúlt évtizedekben, elsősorban Németországban, ahol a kurd kisebbség száma meghaladhatja az 1 millió föt.

47 Andrea Glioti: Kurdish Group Gaining Autonomy in Northern Syria, [online], 2013. 05. 07. Forrás: al-monitor.com [2019. 10. 28.]

48 Egeresi Zoltán: Törökország afríni hadjárata, Nemzet és Biztonság, 10. évf., 2018/2, 30-31. o.; Patrick CLAwson (szerk.): Syrian Kurds as a U.S. Ally, [online], The Washington Institute for Near East Policy, Washington, D.C., 2016, 52-59. o. Forrás: washingtoninstitute.org [2019. 10. 28.]

49 Arany Anett - N. Rózsa Erzsébet - Szalai Máté: Az Iszlám Állam Kalifátusa, Osiris Kiadó, Budapest, 2016, 256-259. o. 
török katonából és a török erőkkel szövetséges 20-22 ezer arab és türkmén fegyveresből álló támadóerővel a török támadásra már régóta számító kurd Népi Védelmi Erők 8-10 ezer fös összlétszámú egységei vették fel a harcot. Az alig több mint két hónapig tartó török hadmüvelet eredményeként a török erők végül elfoglalták és továbbra is ellenőrzésük alatt tartják Afrín térségének nagyrészét, köztük Afrín városát is.

A harmadik, Béke Forrása fedőnevü kurdok elleni török hadműveletre éppen e tanulmány elkészítésének idején került sor. 2019. október 9-én a török fegyveres erők a szíriai ellenzéki erőkkel közösen egy légitámadásokkal és tüzérségi tűzzel előkészített szárazföldi offenzívát indítottak az északkelet-szíriai kurd milíciák ellen, miután a megelőző napokban Donald Trump amerikai elnök „váratlanul” úgy döntött, kivonja az amerikai katonákat Szíriából, ezzel zöld utat adva a török hadműveletnek. ${ }^{50}$ Törökország szerint a katonai akciójuknak a török-szír határ menti „terrorista korridor” felszámolása a célja. Azaz az Egyesült Államok által támogatott SDF gerincét adó, a Délkelet-Törökországban 1984 óta fegyveres harcot vívó, az USA és az EU által is terroristaszervezetnek tekintett Kurd Munkáspárthoz - Törökország szerint szorosan - kötődő YPG fegyvereseinek és létesítményeinek a határövezetből történő eltávolítása, így a bennük a török elnök által látni vélt fenyegetés elhárítása. Ankara az offenzívával egy „biztonsági zóna” kialakítását is elő akarja készíteni, ahova a jelenleg Törökországban tartózkodó 3,6 millió szíriai menekült egy része vissza is térhetne, bár ez azt jelentené, hogy eddig föleg kurdok lakta területekre telepítenének be arab menekülteket. Tekintettel arra, hogy a szíriai kurdok voltak az Egyesült Államok fő szárazföldi szövetségesei az Iszlám Állam elleni harcban az előző években, az ellenük irányuló török offenzíva az egyik leglényegesebb fordulat az immáron több mint nyolc éve tartó, regionális és nagyhatalmak részvételével már korábban nemzetközivé szélesedett szíriai polgárháború alakulásában, az amerikaiaknak a kurdok mögüli kihátrálását pedig többen "hátba szúrásként”, a kurdok egyenesen „árulásként” értékelték. ${ }^{51}$

Hogy az amerikai elnök mennyire nem lehetett tisztában döntésének a súlyával, az is jól mutatja, hogy a török-amerikai szövetség jelentőségét lebecsülve Trump újságíróknak úgy nyilatkozott, hogy „a kurdok nem segítettek nekünk a második világháborúban, nem voltak ott a normandiai partraszállásnál", amire a nemzetközi sajtó is felfigyelt. ${ }^{52}$ A kurdok mögüli kihátrálás és a török offenzíva azonban meghatározó jelentőségű a szíriai polgárháború további menetében. Aszad szíriai elnök és az őt támogató Oroszország és Irán járhat a legjobban, amennyiben az Egyesült Államok katonái tényleg teljesen kivonulnak Szíriából. A szíriai kormányerők végre újra ellenőrzésük alá vonhatnak olyan területeket, ahonnan még évekkel ezelőtt kiszorultak, és az amerikai katonai jelenlét miatt eddig nem állt módjukban visszaszerezni. Most viszont a törökök által megtámadott kurdokkal együttműködésben ismét bevonulhatnak az északkelet-szíriai kurd területekre. ${ }^{53}$

50 Karen DeYoung et al.: Republicans assail Trump's decision to pull troops from northern Syria as Turkey readies offensive [online], 2019. 10. 08. Forrás: washingtonpost.com [2019. 10. 26.]

51 Mert OzKan: Turkey opens ground assault on Syria's Kurds; U.S. Republicans turn on Trump, [online], 2019. 10. 09. Forrás: reuters.com [2019. 10. 26.]

52 Karen DeYoung - Missy Ryan - Dan Lamothe: Trump downplays U.S. alliance with Syrian Kurds, saying 'they didn't help us in the Second World War', [online], 2019. 10. 10. Forrás: washingtonpost.com [2019. 10. 26.]

53 Ben Hubbard et al.: Abandoned by U.S. in Syria, Kurds Find New Ally in American Foe, [online], 2019. 10. 13. Forrás: nytimes.com [2019. 10.26.] 
Oroszország, aki eddig nagyjából 5000 orosz katonával és pár tucat harci repülögéppel támogatta az Aszadhoz hü kormányeröket, most újabb alkalmat kapott arra, hogy katonai jelenlétét és politikai befolyását növelje a térségben, az Egyesült Államok és szövetségeseinek a kárára. ${ }^{54}$ Irán az Aszad-rezsim egyik fö regionális szövetségeseként szintén fontos szerepet játszik a szíriai konfliktus alakulásában. Amellett, hogy Teherán több, különböző etnikai összetételü fegyveres milíciát is támogat Szíriában, magának az iráni Forradalmi Gárdának (IRGC) is több ezer fegyverese harcol a térségben. Az iráni vezetők, köztük Hasszán Rohani elnök és Dzsavád Zarif külügyminiszter „aggodalmukat fejezték ki” a szíriai kurdok elleni török offenzíva miatt, hangsúlyozva, hogy a konfliktus rendezésére békés diplomáciai eszközökkel kell megoldást találni az 1998-ban Törökország és Szíria által kötött Adana-megállapodás keretei között, a török erőknek pedig ki kell vonulniuk Szíria területéről. Irán számára az amerikai erők kivonulása egyértelmüen jó hír, ugyanakkor Teherán egyszerre igyekszik a szíriai kurd erők és az Ankara által támogatott szíriai ellenzéki fegyveresek megerősödését is elkerülni. ${ }^{55}$

2019 októberében, még a hadmüvelet megindítását követő hetekben megállapodást kötött egymással Szocsiban Recep Tayyip Erdoğan török és Vlagyimir Putyin orosz elnök az északkelet-szíriai területek ellenőrzéséről, ${ }^{56}$ majd véglegessé vált egy a megelőző napokban Mike Pence amerikai alelnök által tető alá hozott „ideiglenes tűzszünet” is. A megállapodás értelmében a Szíriai Demokratikus Erők gerincét adó kurd YPG fegyvereseinek ki kellett vonulniuk a török határ melletti 30 km-es sávból, a szíriai határ mentén pedig egy $10 \mathrm{~km}$ széles biztonsági zónát alakítottak ki, amelyet az orosz és a török fegyveres erők egymással együttmüködve, közösen ellenőriznek. A török offenzíva által már elfoglalt területeken pedig egy $120 \mathrm{~km}$ széles és $32 \mathrm{~km}$ mélységű területen rögzítették a status quo fenntartását az akkor épp aktuális állapotnak megfelelően Tell-Abjad és Rász el-Ain között. Donald Trump amerikai elnök a török-orosz megállapodás hírét mindössze anynyival kommentálta, hogy itt az ideje, hogy „hagyjuk, hadd harcoljon más ezért a régóta véráztatta homokért”. ${ }^{7}$ Ahogy arra azonban egyes elemzők felhívták a figyelmet, Putyin és Erdoğan konkrétan az egyes területek ellenőrzéséről állapodtak meg. A két vezetó által aláírt 10 pontos megállapodás gyakorlatilag felosztja a régiót, ahol a szíriai kurdok az elmúlt években az Iszlám Államot legyőzve építették saját demokratikus berendezkedésü autonómiájukat. Egyes elemzők szerint ez a megállapodás a szíriai kurd autonóm Rodzsava régió végét jelentheti. ${ }^{58}$

Erdoğan számára a Putyinnal kötött megállapodás teljes sikerként könyvelhető el, hiszen a török elnök már régóta szorgalmazta egy $32 \mathrm{~km}$-es „biztonsági zóna” kialakítását

54 Megan Specia: Winners and Losers in Trump's Troop Withdrawal From Syria, [online], 2019. 10. 15. Forrás: nytimes. com [2019. 10. 26.]

55 Ahmed Авоudouн: How Trump's sellout of the Kurds threw Iran a lifeline in Syria, [online], 2019. 10. 19. Forrás: independent.co.uk [2019. 10. 26.]; Maysam Behravesh: How Iran views the Turkish invasion of northern Syria, [online], 2019. 10. 12. Forrás: middleeasteye.net [2019. 10. 26.]

56 Umut URAs: Turkey, Russia reach deal for YPG move out of Syria border area, [online], 2019. 10. 23. Forrás: aljazeera. com [2019. 10. 24.]

57 Michael Crowley - Lara Jakes: Trump Claims Credit for a Syria Cease-Fire and Says U.S. Role in Region Is Over, [online], 2019. 10. 23. Forrás: nytimes.com [2019. 10. 25.]

58 Jean-Marc Mojon: Russia-Turkey deal shatters Syria Kurd dreams of self-rule, [online], 2019. 10. 23. Forrás: news.yahoo.com [2019. 10. 25.] 
a szíriai határon egyfajta ütközőzónaként az Ankara szerint a törökországi kurd PKK-hoz köthető YPG jelentette terroristafenyegetéssel szemben. A török hadmüveletet megelőző hetekben a török és az amerikai erők közösen járöröztek a határ mentén, és el is kezdték eltávolítani a területről a YPG fegyvereseit és védelmi létesítményeit. A török-orosz megállapodás lényegében ezt az amerikaiakkal elkezdett biztonsági mechanizmust bővítette ki jelentős mértékben, az Egyesült Államok szerepét pedig Oroszország vette át. De nemcsak Törökországnak a szíriai polgárháborúban betöltött szerepe nőtt meg jelentős mértékben, hanem Oroszországé is, mivel ezzel a megállapodással gyakorlatilag Moszkva lett a fö közvetítő a régióban. Mindemellett mindenképpen meg kell jegyezni, hogy az Aszad-rezsim is jól járt, hiszen a szíriai kormányerők hosszú évek után ismét visszatérhettek északkelet-szíriai területekre. ${ }^{59}$ A törökbarát szíriai felkelők, az előző években a konfliktusban gyakorlatilag marginális szerepet betöltő Szabad Szíriai Hadsereg (FSA) szintén lehetőséget kapott arra, hogy korábban elvesztett területeket hódítson vissza. ${ }^{60}$

A szíriai kurdok eddig is számíthattak Oroszország segítségére, hiszen 2011 után Moszkva velük is igyekezett jó kapcsolatokat ápolni. A PYD még irodát is nyithatott az orosz fövárosban, a szíriai kurd vezető politikusok pedig gyakran látogattak Oroszországba. A jó orosz-kurd kapcsolatok egyik eredményeként éppen az orosz-szír fegyveres erők megjelenése akadályozta meg eleinte az újabb török offenzívát az Eufráteszi Pajzs hadművelet után, mivel egy körülbelül 300 fös orosz katonai egység szavatolta Afrín biztonságát, és így az afríni hadjáratra ennek az orosz katonai egységnek a kivonását követően kerülhetett csak sor. ${ }^{61}$ Nem mellesleg megjegyzendő, hogy a török-orosz kapcsolatok a Szovjetunió összeomlását követően sem voltak feszültségtől mentesek, hiszen az 1990-es években Oroszország továbbra is támogatta a marxista ideológiát követő PKK-t, Törökország pedig a csecsen szeparatistákkal szimpatizált, ami nem egyszer vezetett a bizalmatlanságot mélyítő incidensekhez. ${ }^{62}$ Ettől eltekintve azonban a két ország kereskedelmi kapcsolatai az 1990-es évek során fokozatosan javultak, 1992-ben közös kereskedelmi és gazdasági együttmüködési kormányközi tanácsot hoztak létre, majd pár nappal később a bilaterális kapcsolatukat rögzítő szerződést is aláírták. Ezt követően 1994-ben katonai, majd kulturális és tudományos együttmüködésről született hivatalos megállapodás. 1997-re összesen hét kormányközi megállapodást, szerződést és protokollt írtak alá, amelyek közül talán a legfontosabb az orosz földgázszállításról szólt Törökországba a Fekete-tengeren keresztül. ${ }^{63}$

A 2003-as iraki invázió során Törökország nem támogatta az amerikai katonai beavatkozást, és azt elutasítva nem is engedélyezte, hogy törökországi területről katonai müvelet induljon Észak-Irak irányába, a török politikai vezetés 2007-ben már a függetlenség útján jelentős eredményeket elérő észak-iraki kurdokkal szemben tervezett hadműveleteket, amelyeket az iraki kormány és elsősorban az Egyesült Államok tiltakozása miatt nem

59 Lara Seligman - Elias Groll - Robbie Gramer: How Turkey and Russia Carved Up Northern Syria, [online], 2019. 10. 23. Forrás: foreignpolicy.com [2019. 10. 25.]

60 Carlotta Gall: Syrian Rebels See Chance for New Life With Turkish Troops, [online], 2019. 10. 08. Forrás: nytimes.com [2019. 11. 06.]

61 EgERESI: i. m., 37.

62 Ian TraYnoR: Chechnya fuels Russian-Turkish tension, [online], 2001. 04. 26. Forrás: theguardian.com [2019. 11. 21.]

63 VASILIEV: i. m., 331-332. 
hajtottak végre. Ekkor már láthatóvá vált, hogy Törökország elsősorban a saját biztonsági érdekeit igyekszik előnyben részesíteni, akár az Egyesült Államokkal szembehelyezkedve is. Végül Törökország a 2003-as amerikai inváziót követően először 2008 februárjában hajtott végre egy korlátozott szárazföldi katonai akciót Irakban a PKK ellen. ${ }^{64}$ Ezt követően 2017 áprilisában, Szíriában és Irakban is hajtott végre légitámadásokat, ${ }^{65}$ újabb szárazföldi müveletet azonban csak 2019 májusában indított kurd harcosok ellen Észak-Irak Hakurk régiójában. ${ }^{66}$

\section{Az Egyesült Államok szíriai szerepvállalása}

A szíriai válság első szakaszában az Egyesült Államok is fokozott figyelemmel kísérte az eseményeket és igyekezett óvatosan reagálni a fejleményekre. Barack Obama elnöksége első évében együttműködést szorgalmazó külpolitikát kívánt folytatni még Szíriával is, amelynek jeleként 2010 februárjában ismét amerikai nagykövet érkezett Damaszkuszba. ${ }^{67}$ Ugyanakkor az Obama-adminisztráció már a szíriai ellenzéki tüntetéseknek az elejétől kezdve kiállt az Aszad-rezsimmel szembeni megmozdulások mellett, és mint később kiderült, a CIA és más amerikai ügynökségek titokban támogatták is az ellenzéki erőket. ${ }^{68}$ Washington számára a szíriai események többek között a libanoni Hezbollah és a palesztin Hamász szíriai tevékenysége, a Damaszkusz és Irán közötti együttműködés erősödése, és az Aszad-rezsimnek a zsidó állammal való szembenállása miatt is fontos.

A szíriai polgárháború kibontakozása során az Egyesült Államok kezdetben fegyvereket nem tartalmazó szállítmányokkal segítette a szíriai ellenzéket és a 2011 nyarán szíriai disszidensek által létrehozott Szabad Szíriai Hadsereget, egészen 2013 végéig. Ezt követően két kiképzési programot is indítottak a szíriai ellenzéki erők megerősítésének céljából. Az első ilyen program 2014-ben indult azzal a céllal, hogy 15 ezer felkelö törökországi kiképzésével és felszerelésével egy ütőképes ellenzéki fegyveres erőt állítsanak ki az Iszlám Állammal szembeni harcra három éven belül. Ez a kísérlet azonban gyakorlatilag másfél éven belül csúfos kudarcba fulladt, miután 500 millió amerikai dollár elköltését követően is csupán 54 embert sikerült kiképezni, akiket 2015 nyarán már az első bevetésük során elfogott az an-Núszra Front. ${ }^{69}$ A Pentagon kiképzési programjával párhuzamosan 2013-tól a CIA-nak is futott egy több mint 1 milliárd dolláros titkos kiképzési és felfegyverzési programja Törökországban és Jordániában (Timber Sycamore kódnéven), amellyel sikerült is részsikereket elérni. A 2015-ös orosz katonai intervenció azonban alaposan megtépázta az amerikai hírszerzés által támogatott szíriai ellenzéki erőket, ráadásul jelentések

64 Alissa J. Rubin - Sabrina Tavernise: Turkish Troops Enter Iraq in Pursuit of Kurdish Militants, [online], 2008. 02.23. Forrás: nytimes.com [2019. 11.21.]

65 Isabel Coles - John DAvison: Turkish jets strike Kurdish fighters in Syria, Iraq’s Sinjar, [online], 2017. 04. 25. Forrás: reuters.com [2019. 11.21.]

66 Turkey launches operation against PKK fighters in northern Iraq, [online], 2019. 05. 28. Forrás: aljazeera.com [2019. 11. 21.]

67 Ewen MacAskill: US appoints first ambassador to Damascus since 2005, [online], 2010. 02. 17. Forrás: theguardian. com [2019. 11. 01.]

68 Mark Hosenball: Obama authorizes secret support for Syrian rebels, [online], 2012. 08. 02. Forrás: reuters.com [2019. 11. 01.]

69 Ian BLACK: US axes \$500m scheme to train Syrian rebels, says NYT, [online], 2015. 10. 09. Forrás: theguardian.com [2019. 11.23.] 
szerint a CIA által biztosított fegyverek egy része az an-Núszra Front kezére jutott. Négy év után a titkos program eredményeit és kudarcait is figyelembe véve Mike Pompeo 2017 augusztusában, akkor még a CIA igazgatójaként, végül a kiképzési és felfegyverzési program leállítását javasolta Donald Trump amerikai elnöknek. ${ }^{70}$ Ezek mellett a kiképzési programok mellett 2014 őszén egy nemzetközi katonai intervenció keretében indult légi hadjárat az Iszlám Âllam teljes felszámolása, illetve ismételt megerősödésének elkerülése érdekében.

Az első alkalom, hogy az Egyesült Államok ténylegesen fegyveres erőt alkalmazott az Aszad-rezsimmel szemben, 2017-ben volt, miután Donald Trump amerikai elnök utasítására rakétatámadást hajtottak végre egy szíriai légi bázis ellen, válaszul egy az Aszadrezsimhez köthető észak-szíriai vegyifegyver-támadásra, amelyben több mint 70-en vesztették életüket, a sebesültek száma pedig meghaladta a 100 föt. ${ }^{71} 2018$ áprilisában egy újabb, 40 áldozatot követelő szíriai vegyifegyver-támadást követően Trump az egy évvel korábbinál kétszer erősebb rakétatámadás végrehajtására adott utasítást három, a vegyifegyver-kutatáshoz köthető szíriai célpont ellen. ${ }^{72} \mathrm{E}$ rakétatámadások előzményeként meg kell említeni, hogy 2012 augusztusában Obama újságírók előtt kijelentette, hogy amennyiben az Aszad-rezsim vegyifegyvert alkalmazna a szíriai felkelőkkel szemben, azzal átlépné a képzeletbeli „vörös vonalat”, ami nem maradna következmények nélkül. Egy évvel később, 2013 nyarán a szíriai kormányerők vegyifegyvert (szarin gázt) vetettek be az ellenzéki erőkkel szemben, a támadás során pedig több mint 1400 ember vesztette életét. Az Obamaadminisztráció egyfajta válaszként akkor kilátásba helyezett egy korlátozott mértékű katonai beavatkozást, végül azonban a Fehér Ház megállapodást kötött Oroszországgal a szíriai vegyifegyverkészletek felszámolásáról. ${ }^{73}$

2018-ban a Trump-adminisztráció új Szíria-politikája jelentős mértékben bővítette az Egyesült Államok szíriai szerepvállalásának célkitüzéseit, amelynek értelmében a túl korai csapatkivonást elkerülve tartós amerikai katonai jelenlétre lehetett számítani az Iszlám Állammal szembeni hatékony fellépés, az Aszad-rezsim féken tartása és az iráni befolyás ellensúlyozása érdekében. ${ }^{74}$ Miközben Trump elnök többször is megemlítette, hogy tulajdonképpen szeretné minél hamarabb kivonni az amerikai erőket Szíriából, 2018 szeptemberében még úgy nyilatkozott, hogy az akkor az országban tartózkodó 2200 katona akár korlátlan ideig is maradhat, amennyiben Irán feltartóztatása mindenképpen szükségessé teszi az Egyesült Államok katonai jelenlétét. ${ }^{75}$

70 Mark Mazzetti - Adam Goldman - Michael S. Schmidt: Behind the Sudden Death of a \$1 Billion Secret C.I.A. War in Syria, [online], 2017. 08. 02. Forrás: nytimes.com [2019. 11. 23.]

${ }^{71}$ Spencer ACKerman et al.: Syria missile strikes: US launches first direct military action against Assad, [online], 2017. 04. 07. Forrás: theguardian.com [2019. 11.21.]

72 Helene Cooper - Thomas Gibbons-Neff - Ben Hubbard: U.S., Britain and France Strike Syria over Suspected Chemical Weapons, [online], 2018. 04. 13. Forrás: nytimes.com [2019. 11. 27.]

73 Alex WARD: How Obama’s “red line” fiasco led to Trump bombing Syria, [online], 2018. 04. 15. Forrás: vox.com [2019. 11. 27.]

74 Julian Borger - Patrick Wintour - Kareem Shaheen: US military to maintain open-ended presence in Syria, Tillerson says, [online], 2018. 01. 17. Forrás: theguardian.com [2019. 11. 23.]

75 John Haltiwanger: Trump now plans to keep US troops in Syria until Iran gets out, which means America may never leave, [online], 2018. 09. 24. Forrás: businessinsider.com [2019. 11.23.] 
Jól mutatja a Trump-adminisztráció politikájának kiszámíthatatlanságát, hogy mindezek után december 19-én Trump egy Twitter-posztban bejelentette, hogy sikerült legyőzni az Iszlám Államot, majd parancsot adott az amerikai katonák azonnali kivonására Szíriából, a katonai és civil tanácsadóinak a túl gyors csapatkivonással kapcsolatos fenntartásai és aggodalmai ellenére. ${ }^{76}$ Trump hirtelen meghozott döntését olyan heves kritika érte minden politikai irányból, hogy eleinte hajlandónak mutatkozott a csapatkivonás fokozatos végrehajtására, majd a Szíriából kivont katonákat a szomszédos Irakban állomásoztatta volna, végül pedig 2019 februárjában beleegyezett abba, hogy 400 amerikai katona Szíriában maradjon. ${ }^{77}$ Ezt követően az USA által támogatott Szíriai Demokratikus Erőknek március 24-én sikerült az Iszlám Állam által ellenőrzött területek maradékát is elfoglalni, s így büszkén jelenthették be a szélsőséges iszlamista terrorszervezet felett aratott katonai győzelmet. ${ }^{78} 2019$. október 27 -én pedig az amerikai különleges erők idlibi rajtaütése során életét vesztette a szervezet vezetője, Abu Bakr al-Bagdadi is. ${ }^{79}$ A Bagdadi halálát eredményező amerikai katonai akciót megelőzően október 7-én Trump elnök végül kivonta az amerikai erőket Északkelet-Szíriából, szabad utat adva a kurdok elleni török hadmüveletnek, fokozva az amúgy sem egyszerủ szíriai válság komplexitását. ${ }^{80}$ Míg azonban az északkelet-szíriai területekről kivonták az amerikai katonákat, Bagdadi halálát követően páncélos erőket vezényeltek át Irakból a kelet-szíriai Deir ez-Zór térségébe az ottani olajmezők és olajlétesítmények biztosítására. ${ }^{81}$

\section{Konklúzió}

A szíriai polgárháború azért is érdemel különös figyelmet, mert a válság kibontakozásával újra fellángolt a regionális hatalmi harc, és így olyan külső szereplők avatkoztak be a konfliktus alakulásába, akik az arab tavasz eseményei által érintett más országokban inkább visszafogottabb politikát követtek. ${ }^{82} \mathrm{~A}$ polgárháború nyolc éve alatt már három ország avatkozott be fegyveres erővel. Először Irán igyekezett az Aszad-rezsim segítségére, eleinte fegyverszállítmányokkal, egyéb haditechnikai eszközökkel és kiképzők biztosításával támogatta a szíriai kormányerőket, majd az iráni Forradalmi Gárda és a Teherán által támogatott

76 Mark Landler - Helene Cooper - Eric Schmitt: Trump to Withdraw U.S. Forces From Syria, Declaring 'We Have Won Against ISIS', [online], 2018. 12. 19. Forrás: nytimes.com [2019. 11. 23.]

77 Mark Landler - Helene Cooper: In Latest Shift, Trump Agrees to leave 400 Troops in Syria, [online], 2019. 02.22. Forrás: nytimes.com [2019. 11.23.]

78 Kim HjelmgaArd: American-backed Syrian force declares victory over Islamic State, [online], 2019. 03. 24. Forrás: eu.usatoday.com [2019. 11. 23.]

79 James Griffiths et al.: Trump: ISIS leader Abu Bakr al-Baghdadi is dead, [online], 2019. 10. 27. Forrás: edition.cnn. com [2019. 10. 27.]; ISIL chief Abu Bakra 1-Baghdadi killed in Syria, confirms Trump, [online], 2019. 10. 27. Forrás: aljazeera.com [2019. 10. 27.]; Al Jazeera English (Official YouTube Channel): WATCH: Donald Trump confirms death of ISIL chief al-Baghdadi in US raid, [online], 2019. 10. 27. Forrás: youtube.com [2019. 10. 27.]; Peter BAKER - Eric Schmitт - Helene Cooper: ISIS Leader al-Baghdadi Is Dead, Trump Says, [online], 2019. 10. 27. Forrás: nytimes.com [2019. 10.27.]

80 Trump makes way for Turkey operation against Kurds in Syria, [online], 2019. 10. 17. Forrás: bbc.com [2019. 11. 23.]

81 Julian BORGER - Martin Chulov: US deploying more troops around Syria oil fields after killing of Isis leader, [online], 2019. 10. 28. Forrás: theguardian.com [2019. 11. 23.]

82 A szíriai polgárháború regionális és nemzetközi dimenziójáról bővebben lásd: Raymond HiNNEBUSCH - Adham SAOULI (szerk.): The War for Syria: Regional and International Dimensions of the Syrian Uprising, Routledge, Abingdon, 2019. 
libanoni Hezbollah is bekapcsolódott a harcokba a rezsim oldalán. ${ }^{83} \mathrm{~A}$ perzsa állam támogatása viszont nem bizonyult elegendőnek, így az összeomlástól végül Oroszország katonai beavatkozása mentette meg az Aszad-rezsimet 2015 öszén. Mindemellett az események alakulását csak tovább bonyolította, hogy az elmúlt években Törökország három szárazföldi hadműveletet is indított Szíria északi területein, a polgárháború során fokozatosan megerősödő kurdok ellen, először 2016 második felében, majd 2018 év elején és végül 2019 őszén. ${ }^{84} \mathrm{E}$ három ország külső intervenciói mellett azonban mindenképpen meg kell említenünk, hogy mindeközben az Egyesült Államok csupán csak korlátozott mértékü és eseti jellegü légi csapásokat hajtott végre a szíriai kormányerők ellen, a szárazföldi hadműveletekben elkerülte a közvetlen szerepvállalást, és inkább egyfajta proxyként az ellenzéki fegyveres csoportok, elsősorban pedig a Kurd Népvédelmi Egységek támogatásával igyekezett stratégiai céljait elérni, amelyek közül a prioritás egyértelműen az Iszlám Állam felszámolása lett, amely érdekében nemzetközi koalíciót is szervezett. ${ }^{85} \mathrm{~A}$ szíriai polgárháborúban tehát egyszerre jelenik meg a nagyhatalmi és a regionális hatalmi versengés, ahogy az Egyesült Államok és Oroszország szembenállása mellett megnyilvánul a síita-szunnita ellentét, Szaúd-Arábia és Irán vetélkedése, valamint Törökország fokozódó szerepe is.

A szíriai válság összetettségét, ahogy azt Gazdik Gyula is megjegyezte, éppen az adja, hogy az elmúlt évek során nemzetközivé szélesedett, így már egy olyan fegyveres konfliktussal állunk szemben, amelynek több belső és külső, regionális és nemzetközi, állami és nem állami szereplöje is van, mindemellett pedig bonyolult szektariánus dimenzióval is terhelt. Az Aszad-rezsimmel szembenálló ellenzéki erők támogatójaként sorakozott fel az Egyesült Államok és szövetségesei, az Irán terjeszkedését feltartóztatni kívánó olajmonarchiák, továbbá Izrael, Törökország és Jordánia. A damaszkuszi vezetést a regionális szereplők közül Irán, a libanoni Hezbollah és Irak, míg külső szereplőként Oroszország és Kína támogatják.

A szíriai polgárháború elmúlt éveiben Oroszország a katonai erő és a „kreatív diplomácia" alkalmazásával központi szereplőjévé vált a konfliktusnak az Egyesült Államokkal szemben. 2015-ben direkt katonai intervencióval sietett Aszad segítségére, megfordítva a harcok menetét. Mindeközben az ENSZ Biztonsági Tanácsában valamennyi alkalommal orosz és kínai vétó akadályozta meg Damaszkusz felelösségre vonását, többek között a nemzetközileg tiltott vegyifegyver-használatért, az ENSZ égisze alatt zajló béketárgyalásokkal párhuzamosan pedig Irán és Törökország közreműködésével alternatív békefolyamatot indítottak. Ugyanakkor azt is meg kell jegyezni, hogy ami Oroszország számlájára igazi sikerként könyvelhető el Szíriában, azt nem szándékos erőfeszítésekkel sikerült elérni, hanem gyakorlatilag Moszkva ölébe hullott a nyugati országok és Törökország kiszámíthatatlan politikájának köszönhetően. Putyin számára minden bizonnyal az is üdvözlendő fejle-

\footnotetext{
83 AвDo: $i . m$.

84 A három kurdok elleni szíriai török katonai művelet: Eufráteszi Pajzs hadművelet (2016. augusztus 24. és 2017. március 31. között); Olajág hadművelet (2018. január 20. és március 24. között); Béke Forrása hadművelet (2019. október 9. és október 17. között).

85 Helene Cooper: Obama Enlists 9 Allies to Help in the Battle Against ISIS, [online], 2014. 09. 05. Forrás: nytimes.com [2019. 11.21.]
} 
mény, hogy Oroszország közremüködésével sikerült valamennyire éket verni Törökország és a NATO közé. ${ }^{86}$

A nemzetközi erőfeszítések és a békekezdeményezések ellenére a 21. század egyik legnagyobb humanitárius vészhelyzetét eredményező szíriai polgárháborút továbbra sem sikerült lezárni, annak ellenére sem, hogy az orosz katonai beavatkozással a válság egy új szakaszba lépett. Az elmúlt években inkább a fegyveres konfliktus külső szereplői közötti verseny fokozódását láthattuk a hatalmi befolyásuk növelése érdekében, miközben a föszereplők között gyakorlatilag csak abban volt egyetértés, hogy mindenképpen le kell győzni a 2013 óta Szíriában is aktívan tevékenykedő Iszlám Államot. Ugyanakkor megjegyzendő, hogy még az Iszlám Állam elleni harc sem volt mindenki számára első számú prioritás, sok esetben inkább elsőbbséget élvezett az adott aktor által támogatott erőkkel szemben állók meggyengítése. A különböző szereplők által az ország területén, illetve annak légterében végrehajtott müveletek megnövekedett száma pedig jelentős mértékben fokozta az egymással szemben álló felek közötti komolyabb véletlen fegyveres összecsapás kockázatát. ${ }^{87}$

A helyzet súlyosságára rámutatva David H. Petraeus tábornok egy 2015. szeptemberi szenátusi meghallgatása során találóan „geopolitikai Csernobilnak” nevezte az elhúzódó szíriai konfliktust, hangsúlyozva, hogy a polgárháborúnak egy atomkatasztrófához hasonlóan évtizedekig tartó, a régió országain túl gyakorlatilag az egész nemzetközi közösséget veszélyeztető negatív következményei lehetnek. ${ }^{88}$ Ebben pedig a felelösség a konfliktus valamennyi szereplőjét, azaz a szíriai kormányt, az Iszlám Államot, az ellenzéki fegyveres csoportokat, Oroszországot, az Egyesült Államokat és szövetségeseit egyaránt terheli.

\section{FELHASZNÁLT IRODALOM}

Aвdo, Geneive: How Iran Keeps Assad in Power in Syria, [online], 2011. 08. 25. Forrás: foreignaffairs.com [2019. 11. 01.]

Aвоudoun, Ahmed: How Trump's sellout of the Kurds threw Iran a lifeline in Syria, [online], 2019. 10. 19. Forrás: independent.co.uk [2019. 10. 26.]

Ackerman, Spencer - Pilkington, Ed - Jacobs, Ben - Borger, Julian: Syria missile strikes: US launches first direct military action against Assad, [online], 2017. 04. 07. Forrás: theguardian.com [2019. 11. 21.]

Adamsky, Dmitry: Moscow's Syria Campaign: Russian Lessons for the Art of Strategy, [online], Russie.Nei. Visions, No. 109, 2018. Forrás: ifri.org [2019. 10. 08.]

Adamsky, Dmitry: Putin's Game in Syria, [online], 2016. 04. 03. Forrás: foreignaffairs.com [2019. 10. 23.]

Ahmadian, Hassan - Mohseni, Payam: Iran's Syria strategy: the evolution of deterrence, International Affairs, 95. évf., 2019/2, 341-364. o. DOI: https://doi.org/10.1093/ia/iiy271

Al Jazeera English (Official YouTube Channel): WATCH: Donald Trump confirms death of ISIL chief al-Baghdadi in US raid, [online], 2019. 10. 27. Forrás: youtube.com [2019. 10.27.]

Arany Anett - N. Rózsa Erzsébet - Szalai Máté: Az Iszlám Állam Kalifátusa, Osiris Kiadó, Budapest, 2016. ARsu, Sebnem: Turkish Premier Urges Assad to Quit in Syria, [online], 2011. 11. 22. Forrás: nytimes.com [2019. 10.31.]

86 Ben Hubbard et al.: In Syria, Russia Is Pleased to Fill an American Void, [online], 2019. 10. 17. Forrás: nytimes.com [2019. 11. 25.]

87 GAZDIK: Szíriai válság: „geopolitikai Csernobil”? (I.): i. m., 105-107.

88 Tim Hains: Gen. Petraeus: Syria Has Become A “Geopolitical Chernobyl” Spewing Instability Worldwide, [online], 2015. 09. 22. Forrás: realclearpolitics.com [2019. 11. 19.] 
BAKer, Peter - Schmitt, Eric - Cooper, Helene: ISIS Leader al-Baghdadi Is Dead, Trump Says, [online], 2019. 10. 27. Forrás: nytimes.com [2019. 10. 27.]

Behravesh, Maysam: How Iran views the Turkish invasion of northern Syria, [online], 2019. 10. 12. Forrás: middleeasteye.net [2019. 10. 26.]

Belcastro, Francesco: Syrian Foreign Policy: The Alliances of a Regional Power, Routledge/St. Andrews Syrian Studies Series, London, 2019. DOI: https://doi.org/10.4324/9780429060779

BLACK, Ian: US axes \$500m scheme to train Syrian rebels, says NYT, [online], 2015. 10. 09. Forrás: theguardian. com [2019. 11. 23.]

Borger, Julian - Chulov, Martin: US deploying more troops around Syria oil fields after killing of Isis leader, [online], 2019. 10. 28. Forrás: theguardian.com [2019. 11. 23.]

Borger, Julian - Wintour, Patrick - Shaheen, Kareem: US military to maintain open-ended presence in Syria, Tillerson says, [online], 2018. 01. 17. Forrás: theguardian.com [2019. 11.23.]

Borshchevskaya, Anna: Russia’s Goals Go beyond Damascus, Middle East Quarterly, 25. évf., 2018/1, 1-13. o.

Clawson, Patrick (szerk.): Syrian Kurds as a U.S. Ally, [online], The Washington Institute for Near East Policy, Washington, D.C., 2016. Forrás: washingtoninstitute.org [2019. 10. 28.]

ColEs, Isabel - DAvison, John: Turkish jets strike Kurdish fighters in Syria, Iraq’s Sinjar, [online], 2017. 04. 25. Forrás: reuters.com [2019. 11.21.]

Cooper, Helene - Gibbons-Neff, Thomas - Hubbard, Ben: U.S., Britain and France Strike Syria over Suspected Chemical Weapons, [online], 2018. 04. 13. Forrás: nytimes.com [2019. 11. 27.]

Cooper, Helene: Obama Enlists 9 Allies to Help in the Battle Against ISIS, [online], 2014. 09. 05. Forrás: nytimes. com [2019. 11.21.]

Crowley, Michael - Jakes, Lara: Trump Claims Credit for a Syria Cease-Fire and Says U.S. Role in Region Is Over, [online], 2019. 10. 23. Forrás: nytimes.com [2019. 10. 25.]

Csıki Tamás - GAzDik Gyula: Stratégiai törekvések a szíriai válság kapcsán I., Nemzet és Biztonság, 7. évf., 2013/1-2, 42-65. o.

DeYoung, Karen - Ryan, Missy - Fahim, Kareem - Dadouch, Sarah: Republicans assail Trump's decision to pull troops from northern Syria as Turkey readies offensive, [online], 2019. 10. 08. Forrás: washingtonpost. com [2019. 10. 26.]

DeYoung, Karen - Ryan, Missy - Lamothe, Dan: Trump downplays U.S. alliance with Syrian Kurds, saying 'they didn't help us in the Second World War', [online], 2019. 10. 10. Forrás: washingtonpost.com [2019. 10. 26.]

Egeresi Zoltán: Törökország afríni hadjárata, Nemzet és Biztonság, 10. évf., 2018/2, 30-43. o.

Gall, Carlotta: Syrian Rebels See Chance for New Life With Turkish Troops, [online], 2019. 10. 08. Forrás: nytimes.com [2019. 11. 06.]

GAzDik Gyula: Szíria az „arab tavasz” sodrában, Nemzet és Biztonság, 5. évf., 2012/4, 111-128. o.

GAzDik Gyula: Szíriai válság: „geopolitikai Csernobil”? (I.), Nemzet és Biztonság, 8. évf., 2016/5, 104-120. o.

GLIOTI, Andrea: Kurdish Group Gaining Autonomy in Northern Syria, [online], 2013. 05. 07. Forrás: al-monitor. com [2019. 10. 28.]

GoodarzI, Jubin M.: Syria and Iran: Diplomatic Alliance and Power Politics in the Middle East, Tauris, London, 2006.

Griffiths, James - Ruiz, Joe - Mackintosh, Eliza - Alfonso III, Fernando: Trump: ISIS leader Abu Bakr al-Baghdadi is dead, [online], 2019. 10. 27. Forrás: edition.cnn.com [2019. 10. 27.]

Hains, Tim: Gen. Petraeus: Syria Has Become A “Geopolitical Chernobyl” Spewing Instability Worldwide, [online], 2015. 09. 22. Forrás: realclearpolitics.com [2019. 11. 19.]

Haltiwanger, John: Trump now plans to keep US troops in Syria until Iran gets out, which means America may never leave, [online], 2018. 09. 24. Forrás: businessinsider.com [2019. 11. 23.]

Champion, Marc - Ferziger, Jonathan - Wainer, David: Israel, Saudis Find Common Cause in Warning of Iran Expansionism, [online], 2018. 02. 18. Forrás: bloomberg.com [2019. 11. 22.]

Hannah, John: Russia’s Middle East Offensive, [online], 2016. 09. 13. Forrás: foreignpolicy.com [2019. 10. 23.]

Hatahet, Sinan: Russia and Iran: Economic Influence in Syria, [online], Chatham House, Middle East and North Africa Programme Research Paper, March 2019. Forrás: chathamhouse.org [2019. 10. 08.]

Hinnebusch, Raymond - SAouli, Adham (szerk.): The War for Syria: Regional and International Dimensions of the Syrian Uprising, Routledge, Abingdon, 2019. DOI: https://doi.org/10.4324/9780429201967 
HJelmgaArd, Kim: American-backed Syrian force declares victory over Islamic State, [online], 2019. 03. 24. Forrás: eu.usatoday.com [2019. 11. 23.]

Hosenball, Mark: Obama authorizes secret support for Syrian rebels, [online], 2012. 08. 02. Forrás: reuters. com [2019. 11.01.]

Hubbard, Ben - Savage, Charlie - Schmitt, Eric - Kingsley, Patrick: Abandoned by U.S. in Syria, Kurds Find New Ally in American Foe, [online], 2019. 10. 13. Forrás: nytimes.com [2019. 10. 26.]

Hubbard, Ben - Troianovski, Anton - Gall, Carlotta - Kingsley, Patrick: In Syria, Russia Is Pleased to Fill an American Void, [online], 2019. 10. 17. Forrás: nytimes.com [2019. 11. 25.]

Interview With Syrian President Bashar al-Assad, [online], 2011. 01. 31. Forrás: wsj.com [2019. 10. 29.]

ISIL chief Abu Bakra 1-Baghdadi killed in Syria, confirms Trump, [online], 2019. 10. 27. Forrás: aljazeera.com [2019. 10.27.]

ItANI, Faysal: Geo-economics: Russia and Iran in Syria, Syria Studies, 11. évf., 2019/1, 23-31. o.

Karmanau, Yuras: Naval base in Syria anchors Russia to Mediterranean, [online], 2019. 09. 26. Forrás: navytimes.com [2019. 10. 21.]

Kenner, David: What Russia Gave Syria, A guide to Bashar al-Assad’s arsenal, [online], 2012. 06. 21. Forrás: foreignpolicy.com [2019. 10. 21.]

Landler, Mark - Cooper, Helene - Schmitt, Eric: Trump to Withdraw U.S. Forces from Syria, Declaring 'We Have Won Against ISIS', [online], 2018. 12. 19. Forrás: nytimes.com [2019. 11. 23.]

LANDler, Mark - Cooper, Helene: In Latest Shift, Trump Agrees to leave 400 Troops in Syria, [online], 2019. 02. 22. Forrás: nytimes.com [2019. 11. 23.]

LeE, Jasmine C.: Why the Russian Economy Is Tumbling, [online], 2016. 04. 12. Forrás: nytimes.com [2019. 10. 23.]

Letsch, Constanze: Assad regrets Syrian forces shooting down Turkish fighter plane, [online], 2012. 07. 03. Forrás: theguardian.com [2019. 10.31.]

MACAskill, Ewen: US appoints first ambassador to Damascus since 2005, [online], 2010. 02. 17. Forrás: theguardian.com [2019. 11.01.]

MacFarquhar, Neil - Barnard, Anne: Putin Orders Start of Syria Withdrawal, Saying Goals Are Achieved, [online], 2016. 03. 14. Forrás: nytimes.com [2019. 10. 22.]

Mazzetti, Mark - Goldman, Adam - Schmidt, Michael S.: Behind the Sudden Death of a \$1 Billion Secret C.I.A. War in Syria, [online], 2017. 08. 02. Forrás: nytimes.com [2019. 11. 23.]

McDowall, David: A Modern History of the Kurds, I. B. Tauris, London - New York, 2017.

Mojon, Jean-Marc: Russia-Turkey deal shatters Syria Kurd dreams of self-rule, [online], 2019. 10. 23. Forrás: news.yahoo.com [2019. 10. 25.]

N. Rózsa Erzsébet: Az arab tavasz - A Közel-Kelet átalakulása, Osiris Kiadó - Külügyi és Külgazdasági Intézet, Budapest, 2015.

NAFI, Basheer: Iran's sectarian wars must be confronted, but not with more of the same, [online], 2017. 03. 16. Forrás: middleeasteye.net [2019. 11.22.]

Nichols, Michelle: Russia casts 13th veto of U.N. Security Council action during Syrian war, [online], 2019. 09. 19. Forrás: reuters.com [2019. 10. 22.]

OzKan, Mert: Turkey opens ground assault on Syria’s Kurds; U.S. Republicans turn on Trump, [online], 2019. 10. 09. Forrás: reuters.com [2019. 10. 26.]

Peker, Emre: Syria’s Main Opposition Group Opens First Office in Istanbul, [online], 2011. 12. 14. Forrás: bloomberg.com [2019. 10.31.]

Póti László - N. RózsA Erzsébet: Oroszország Szíriában: nem második ukrán front, Külügyi és Külgazdasági Intézet, KKI-elemzések, E-2015/38.

Pukhov, Ruslan: Why Russia Is Backing Syria, [online], 2012. 07. 06. Forrás: nytimes.com [2019. 10. 22.]

RÁCz András - JójÁrT Krisztián: A Deir ez-Zór incidens: amerikai légicsapás orosz zsoldosok ellen Szíriában, Nemzet és Biztonság, 10. évf., 2018/2, 57-65. o.

Rubin, Alissa J. - Tavernise, Sabrina: Turkish Troops Enter Iraq in Pursuit of Kurdish Militants, [online], 2008. 02. 23. Forrás: nytimes.com [2019. 11. 21.]

Russia joins war in Syria: Five key points, [online], 2015. 10. 01. Forrás: bbc.com [2019. 10. 22.] 
SACHs, Susan: Rafik Hariri, Ex-Premier of Lebanon, Dies at 60, [online], 2005. 02. 15. Forrás: nytimes.com [2019. 10.21.]

SAdJADPOUR, Karim: Iran's Real Enemy in Syria, [online], 2018. 04. 16. Forrás: theatlantic.com [2019. 11. 22.]

SAFI, Michael: Tunisia election: 'Robocop' Kais Saied wins presidential runoff, [online], 2019. 10. 14. Forrás: theguardian.com [2019. 11. 05.]

Secker, Bradley - Dumalaon, Janelle: Turkey authorizes military operations in Syria, [online], 2012. 10. 05. Forrás: eu.usatoday.com [2019. 10.31.]

Seligman, Lara - Groll, Elias - Gramer, Robbie: How Turkey and Russia Carved Up Northern Syria, [online], 2019. 10. 23. Forrás: foreignpolicy.com [2019. 10. 25.]

Selján Péter: Oroszország és a szíriai polgárháború, Nemzet és Biztonság, 8. évf., 2016/5, 14-30. o.

SLY, Liz: Turkey strikes back at Syria after shell kills at least 5 Turkish civilians, [online], 2012. 10. 03. Forrás: washingtonpost.com [2019. 10.31.]

Specia, Megan: Winners and Losers in Trump’s Troop Withdrawal From Syria, [online], 2019. 10. 15. Forrás: nytimes.com [2019. 10. 26.]

Sz. Bíró Zoltán: Oroszország külpolitikája (2012-2016): a nagyhatalmiság kísértése, Nemzet és Biztonság, 8. évf., 2016/6, 25-47. o.

TÁlas Péter - VArga Gergely: Stratégiai törekvések a szíriai válság kapcsán II., Nemzet és Biztonság, 6. évf., 2013/1-2, 66-86. o.

Terrill, W. Andrew: Iran's Strategy for Saving Asad, Middle East Journal, 69. évf., 2015/2, 222-236. o. DOI: https://doi.org/10.3751/69.2.13

TraynOR, Ian: Chechnya fuels Russian-Turkish tension, [online], 2001. 04. 26. Forrás: theguardian.com [2019. 11. 21.]

Trump makes way for Turkey operation against Kurds in Syria, [online], 2019. 10. 17. Forrás: bbc.com [2019. 11.23.]

Turkey launches operation against PKK fighters in northern Iraq, [online], 2019. 05. 28. Forrás: aljazeera.com [2019. 11.21.]

Ukman, Jason - Sly, Liz: Obama: Syrian President Assad must step down, [online], 2011. 08. 18. Forrás: washingtonpost.com [2019. 11. 22.]

URAS, Umut: Turkey, Russia reach deal for YPG move out of Syria border area, [online], 2019. 10. 23. Forrás: aljazeera.com [2019. 10.24.]

VAsiliev, Alexey: Russia's Middle East Policy: From Lenin to Putin. Durham Modern Middle East and Islamic World Series (Book 46), Routledge, Abingdon, 2018. DOI: https://doi.org/10.4324/9781315121826

WARD, Alex: How Obama's "red line" fiasco led to Trump bombing Syria, [online], 2018. 04. 15. Forrás: vox. com [2019. 11.27.] 